\title{
48. EVOLUTION OF THE SOUTHERN KERGUELEN PLATEAU DEDUCED FROM SEISMIC STRATIGRAPHIC STUDIES AND DRILLING AT SITES 748 AND $750^{1}$
}

\author{
Bernard Fritsch, ${ }^{2}$ Roland Schlich, ${ }^{2}$ Marc Munschy, ${ }^{2}$ Fatmir Fezga, ${ }^{2}$ and Millard F. Coffin ${ }^{3}$
}

\begin{abstract}
The evolution of the Raggatt Basin in the Southern Kerguelen Plateau, since the Late Cretaceous, was deduced from seismic stratigraphic interpretations of the multichannel seismic data and Ocean Drilling Program results at Sites 748 and 750 . Synthetic seismograms were built using in situ and corrected core velocity values. Corrections were based on Wyllie's law, and exponential variations of porosity were calculated from logging data at Site 750 . The synthetic seismograms in conjunction with the seismic sections allowed us to correlate the lithologic units and the seismic sequences.

After the emplacement of oceanic basaltic basement at $110 \mathrm{Ma}$, the Late Cretaceous history of the Raggatt Basin was controlled by two rifting episodes at $88 \mathrm{Ma}$ to the east and at $66 \mathrm{Ma}$ to the west. The first rifting episode, with an axis of extension striking northwest-southeast, formed the eastern flank of the Southern Kerguelen Plateau. The second rifting episode, along a north-south axis, formed the $77^{\circ} \mathrm{E}$ Graben. At $45-42 \mathrm{Ma}$, the separation by seafloor spreading of the Kerguelen Plateau-Labuan Basin and Broken Ridge-Diamantina Zone marks a third rifting episode, which was recorded on the Southern Kerguelen Plateau by erosion.
\end{abstract}

\section{INTRODUCTION}

The Kerguelen Plateau is a major feature of the central part of the southern Indian Ocean. It is a large bathymetric high, standing $2-4 \mathrm{~km}$ above the adjacent ocean basins, and is $200-600 \mathrm{~km}$ wide. The plateau extends about $2000 \mathrm{~km}$ between $46^{\circ}$ and $64^{\circ} \mathrm{S}$. It has been divided into two distinct domains (Schlich, 1975; Houtz et al., 1977).

The Northern Kerguelen Plateau, located between $46^{\circ}$ and $54^{\circ} \mathrm{S}$, lies in $<1000 \mathrm{~m}$ water depth and includes the Kerguelen, Heard, and McDonald volcanic islands. The structure and evolution of the Northern Kerguelen Plateau have been studied in detail by Schlich et al. (1971), Guglielmi (1982), Wicquart (1983), Wicquart and Fröhlich (1986), and Munschy and Schlich (1987). Furthermore, two sites (Site 736 and 737) were drilled during Ocean Drilling Program (ODP) Leg 119 (Barron, Larsen, et al., 1989).

The Southern Kerguelen Plateau (SKP), located between $57^{\circ}$ and $64^{\circ} \mathrm{S}$, lies in water depths of $1500-3000 \mathrm{~m}$ and includes a large sedimentary basin, the Raggatt Basin. This basin, first delineated and described by Ramsay et al. (1986), Leclaire et al. (1987a, 1987b), Colwell et al. (1988), and Schlich et al. (1988), covers a triangle area with the longest side, $450 \mathrm{~km}$ long, in a northwest-trending direction and with a northeastsouthwest maximum extent of $250 \mathrm{~km}$ (Fig. 1). The eastern boundary of the Raggatt Basin is marked by a fault scarp that separates the Southern Kerguelen Plateau from the Labuan Basin (Coffin et al., 1986, 1990; Rotstein et al., in press). To the west, the basin abuts the north-south faults of the $77^{\circ} \mathrm{E}$ Graben and, to the southwest, it is bounded by a large basement block, the Banzare Bank. To the south, the basin

\footnotetext{
${ }^{1}$ Wise, S. W., Jr., Schlich, R., et al., 1992. Proc. ODP, Sci. Results, 120: College Station, TX (Ocean Drilling Program).

2 Institut de Physique du Globe, Université Louis Pasteur, Laboratoire de Géophysique Marine (CNRS URA 323), 5 rue René Descartes, 67084 Strasbourg Cedex, France.

${ }^{3}$ Bureau of Mineral Resources, Geology and Geophysics, G.P.O. Box 378 , Canberra ACT 2601, Australia (present address: Institute for Geophysics, University of Texas at Austin, 8701 Mopac Boulevard, Austin, TX 78759-8345, U.S.A.).
}

may continue to the southernmost reaches of the SKP. The basin is deformed by numerous normal faults trending along two main directions: a dominant north-south direction, mainly in its western part, and a northwest-southeast direction, parallel to the flank of the plateau, restricted to the eastern part (Houtz et al., 1977; Coffin et al., 1990; Rotstein et al., 1990). Munschy et al. (this volume) described the structure and evolution of the central part of the Kerguelen Plateau, located between $54^{\circ}$ and $57^{\circ} \mathrm{S}$; in particular, they correlated the observed north-south direction of the tectonic features with the rifting event that formed the $77^{\circ} \mathrm{E}$ Graben.

The 1985 and 1986 multichannel seismic (MCS) surveysRig Seismic Cruise 02 (RS 02; Ramsay et al., 1986) and Marion Dufresne Cruise 47 (MD 47; Schlich et al., 1988)allowed the definition of seven seismic stratigraphic sequences in the Raggatt Basin (Table 1; Coffin et al., 1990). These sequences are identified on the southwest-northeast composite profile shown in Figure 2. The age of the sequences (Table 1) and the sedimentary history of the Raggatt Basin were deduced from dredge and piston-core results (Leclaire et al., 1987a, 1987b). Internal basement reflectors characterize much of the SKP, and Schaming and Rotstein (1990) suggested that a large part of the plateau is underlain by volcanic flows. They also defined basement synforms and ridges. Based upon these observations, Rotstein et al. (1990) considered the Raggatt Basin to be the result of a pre-existing basement synform surrounded by basement ridge complexes at its northeastern and southwestern edges, respectively. The Raggatt Basin was drilled during Leg 120 at Sites 748,750 , and 751 , and preliminary correlations of lithostratigraphic units with seismic sequences were proposed (Schlich, Wise, et al., 1989, see "Site 748," "Site 750," and "Site 751" chapters).

In this paper, we present the results of a detailed correlation study of the seismic reflectors identified on the MCS data and the lithologic units recognized at Sites 748 and 750 . The correlation is based on synthetic seismograms computed from all available data, including logging and physical properties. Some significant modifications are proposed with regard to the previous interpretation (Schlich, Wise, et al., 1989). The results were used to interpret the southwest-northeast composite MCS section (Profiles RS 02-27, MD 47-05, and RS 


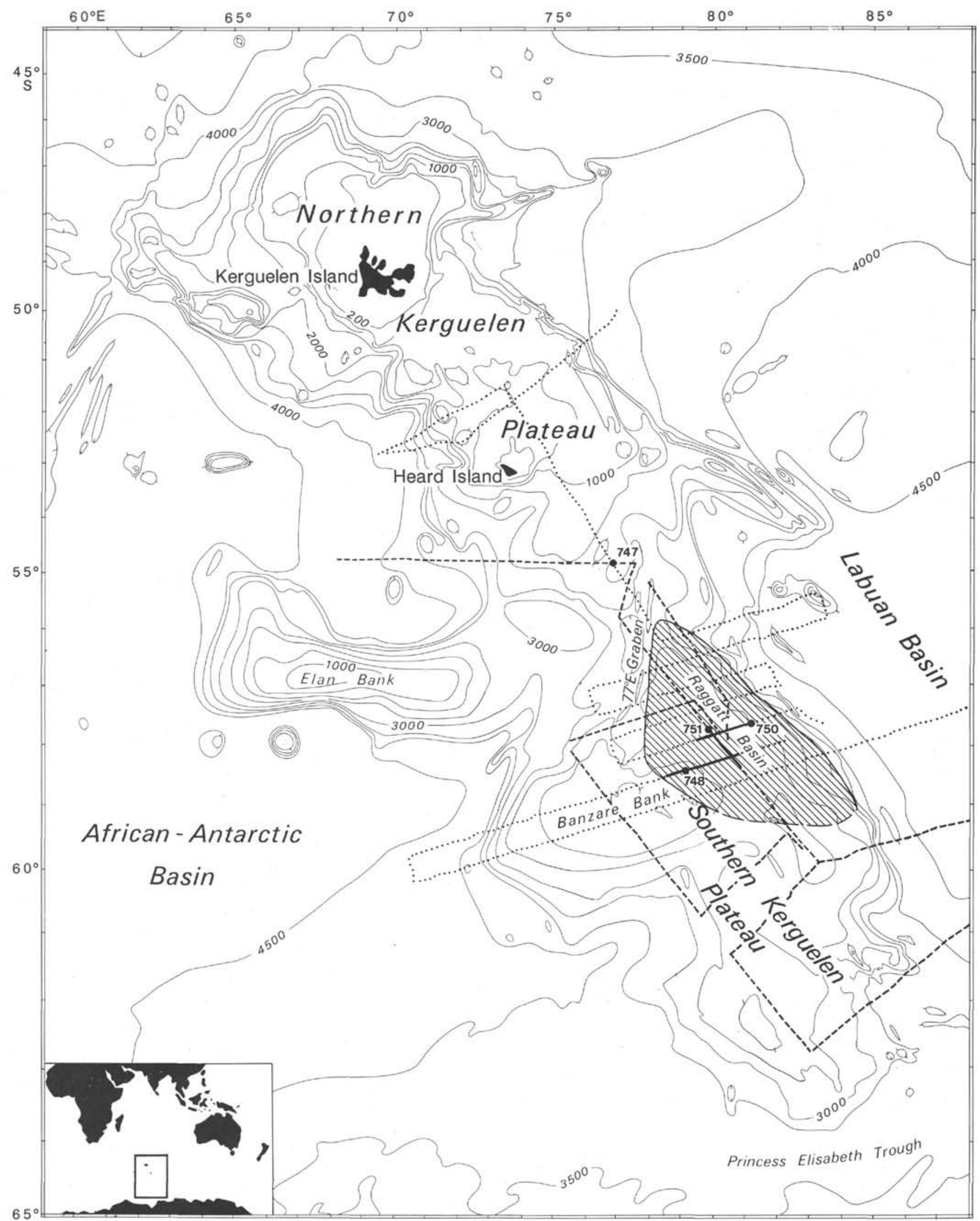

Figure 1. Bathymetric map (in meters) of the Kerguelen Plateau after Schlich et al. (1987). The heavy lines correspond to MCS profiles used to connect, from west to east, Sites 748 (RS 02-27), 751 (MD 47-05), and 750 (RS 02-24). 
Table 1. Description of the seismic sequences, Sites 748 and 750.

\begin{tabular}{|c|c|c|c|c|c|c|c|c|}
\hline \multirow[b]{2}{*}{ Sequence } & \multirow[b]{2}{*}{ Upper boundary } & \multirow[b]{2}{*}{ Lower boundary } & \multicolumn{4}{|c|}{ Seismic characteristic } & \multirow{2}{*}{$\begin{array}{l}\text { Maximum } \\
\text { thickness } \\
\text { (s) }\end{array}$} & \multirow[b]{2}{*}{ Age } \\
\hline & & & Configuration & Continuity & Amplitude & Frequency & & \\
\hline NQ1 & $\begin{array}{l}\text { Seafloor, commonly } \\
\text { erosional }\end{array}$ & $\begin{array}{l}\text { Concordant, erosional } \\
\text { at basin margins }\end{array}$ & Parallel & High & High & $\begin{array}{c}\text { Moderate } \\
\text { to high }\end{array}$ & 0.3 & $\begin{array}{l}\text { Holocene to } \\
\text { Miocene }\end{array}$ \\
\hline PN1 & $\begin{array}{l}\text { Concordant, erosional } \\
\text { at basin margins }\end{array}$ & Erosional, onlap & Parallel & Moderate & Low & Moderate & 0.2 & $\begin{array}{l}\text { Miocene to } \\
\text { Oligocene }\end{array}$ \\
\hline P2 & $\begin{array}{l}\text { Concordant, erosional } \\
\text { at basin margins }\end{array}$ & Erosional, onlap & Parallel & Moderate to high & $\begin{array}{l}\text { Low to } \\
\text { moderate }\end{array}$ & $\begin{array}{l}\text { Moderate } \\
\text { to high }\end{array}$ & 0.6 & $\begin{array}{l}\text { Oligocene to } \\
\text { Eocene }\end{array}$ \\
\hline P1 & $\begin{array}{l}\text { Concordant to } \\
\text { erosional; erosional } \\
\text { at basin margins }\end{array}$ & $\begin{array}{l}\text { Downlap adjacent to } \\
\text { mounds; concordant } \\
\text { elsewhere }\end{array}$ & Highly variable & Low to moderate & $\begin{array}{l}\text { Low to } \\
\text { moderate }\end{array}$ & Moderate & 0.4 & $\begin{array}{l}\text { Eocene to Late } \\
\text { Cretaceous }\end{array}$ \\
\hline K3 & $\begin{array}{l}\text { Concordant, erosional } \\
\text { at basin margins }\end{array}$ & $\begin{array}{l}\text { Mounds or erosional, } \\
\text { onlap }\end{array}$ & $\begin{array}{l}\text { Chaotic (mounds), } \\
\text { parallel (elsewhere) }\end{array}$ & $\begin{array}{l}\text { Low high, with } \\
\text { abrupt character } \\
\text { changes }\end{array}$ & Moderate & $\begin{array}{c}\text { Moderate } \\
\text { to low }\end{array}$ & 0.6 & $\begin{array}{l}\text { Paleocene to Late } \\
\text { Cretaceous }\end{array}$ \\
\hline K2 & Concordant & Erosional, onlap & Parallel & High to poor & $\begin{array}{c}\text { Moderate } \\
\text { to high }\end{array}$ & $\begin{array}{l}\text { Moderate } \\
\text { to low }\end{array}$ & 0.5 & $\begin{array}{l}\text { Late to Early } \\
\text { Cretaceous }\end{array}$ \\
\hline K1 & Concordant & Erosional, onlap & Parallel & $\begin{array}{l}\text { Moderate to } \\
\text { poor }\end{array}$ & $\begin{array}{l}\text { Moderate } \\
\text { to low }\end{array}$ & $\begin{array}{l}\text { Moderate } \\
\text { to low }\end{array}$ & 0.5 & \\
\hline Basement & Erosional & $?$ & \multicolumn{5}{|c|}{$\begin{array}{l}\text { Highly variable character ranging from reflection-free to high } \\
\text { amplitude, low frequency dipping reflectors }\end{array}$} & Early Cretaceous \\
\hline
\end{tabular}

Note: Data after Coffin et al. (1990).

02-24) across Sites 748, 750, and 751 in the Raggatt Basin and to clarify the evolution of the SKP for the last $110 \mathrm{~m}$.y. We use the time scale proposed by Kent and Gradstein (1985) for the Cretaceous and by Berggren et al. (1985a, 1985b, 1985c) and Aubry et al. (1988) for the Cenozoic.

\section{SYNTHETIC SEISMOGRAM}

Synthetic seismograms can be used to determine an estimate of the depth (in meters) of a given reflector observed on a seismic section. The characteristics of the seismic source, and the velocity and density parameters of the material are required to compute the synthetic seismograms. We used a computer program based on the reflection coefficient method (Sheriff, 1977; Badley, 1985). The characteristics of the source wavelet, deduced from spectral analysis of the seismic signal along Profiles RS 02-24 (close to Site 750) and RS 02-27 (close to Site 748), allowed us to model the seismic source by a minimum-phase rickert with a frequency of $30 \mathrm{~Hz}$. The impedance $\log$ was built from the velocity and density measurements made at ODP drilling sites, and the synthetic seismogram was obtained by convolution of the impedance log with the seismic source wavelet. To allow us to make comparisons with the processed seismic data, an amplitude gain control was applied to the synthetic traces.

\section{Computation of the Impedance Log at Sites 748 and} 750

At Site 748 the impedance log is only based on core sample measurements. At Site 750 , where the velocity was measured by borehole logging between 52 and $450 \mathrm{~m}$ below seafloor (mbsf), the impedance log was built from the wireline logging velocity for the logged interval and on core sample measurements for the unlogged intervals. When using both discrete density and velocity measurements, the discrepancies between the synthetic seismograms and the seismic traces appear very large. This is clearly related to the scarcity of the measurements; a core sample may not be representative of the formation at a given depth with poor core recovery. Erroneous values, caused by unrepresentative drilling samples, would affect both the density and velocity; thus, the error will be enhanced on the impedance $\log$. To minimize the scattering introduced by density and velocity errors, we built a pseudoimpedance log only based on the core and in situ measured velocities using the following empirical formula:

$$
\text { Impedance }=\text { velocity }{ }^{3 / 2} \text {, }
$$

with velocity in $\mathrm{km} / \mathrm{s}$.

This formulation is justified because density and velocity curves of similar lithologies are roughly proportional, as observed in the physical property determinations (Schlich, Wise, et al., 1989, "Site 748" and "'Site 750" chapters).

The core-derived velocities have to be corrected for in situ conditions. We neglected to take into account the effect of temperature and only considered the confining pressure. The effect of pressure is linked to sediment porosity. Laboratory experiments have shown that compressional wave velocities can increase with pressure by $20 \%$ for effective pressures up to $30 \mathrm{MPa}$ (1-1.5 km sediment thickness) (Gregory, 1976; Tosaya and Nur, 1982; Wyllie et al., 1958; Nur and Murphy, 1981). Only empirical laws deduced from statistical measurements offer the possibility to relate velocity to porosity and to pressure for marine sediments (Nafe and Drake, 1963). The simplest relation between velocity and porosity is Wyllie's law (Wyllie et al., 1962) proposed for clastic rocks:

$$
\frac{1}{V}=\frac{\Phi}{V_{f}}+\frac{(1-\Phi)}{V_{m}}
$$

where $V=$ velocity $(\mathrm{m} / \mathrm{s})$,

$\Phi=$ in-situ porosity,

$V f=$ pore fluid velocity $(\mathrm{m} / \mathrm{s})$, and

$V m=$ matrix velocity $(\mathrm{m} / \mathrm{s})$.

This relation does not account for velocities determined at shallow depths and for high porosities. Nafe and Drake (1963) and Raymer et al. (1980) propose a more precise relation in this case:

$$
\Phi<35 \% \quad V=(1-\Phi)^{2} V_{m}+\Phi V_{f}
$$

and

$$
\Phi>45 \% \frac{1}{d V^{2}}=\frac{\Phi}{d_{f} V_{f}^{2}}+\frac{(1-\Phi)}{d_{m} V_{m}^{2}},
$$



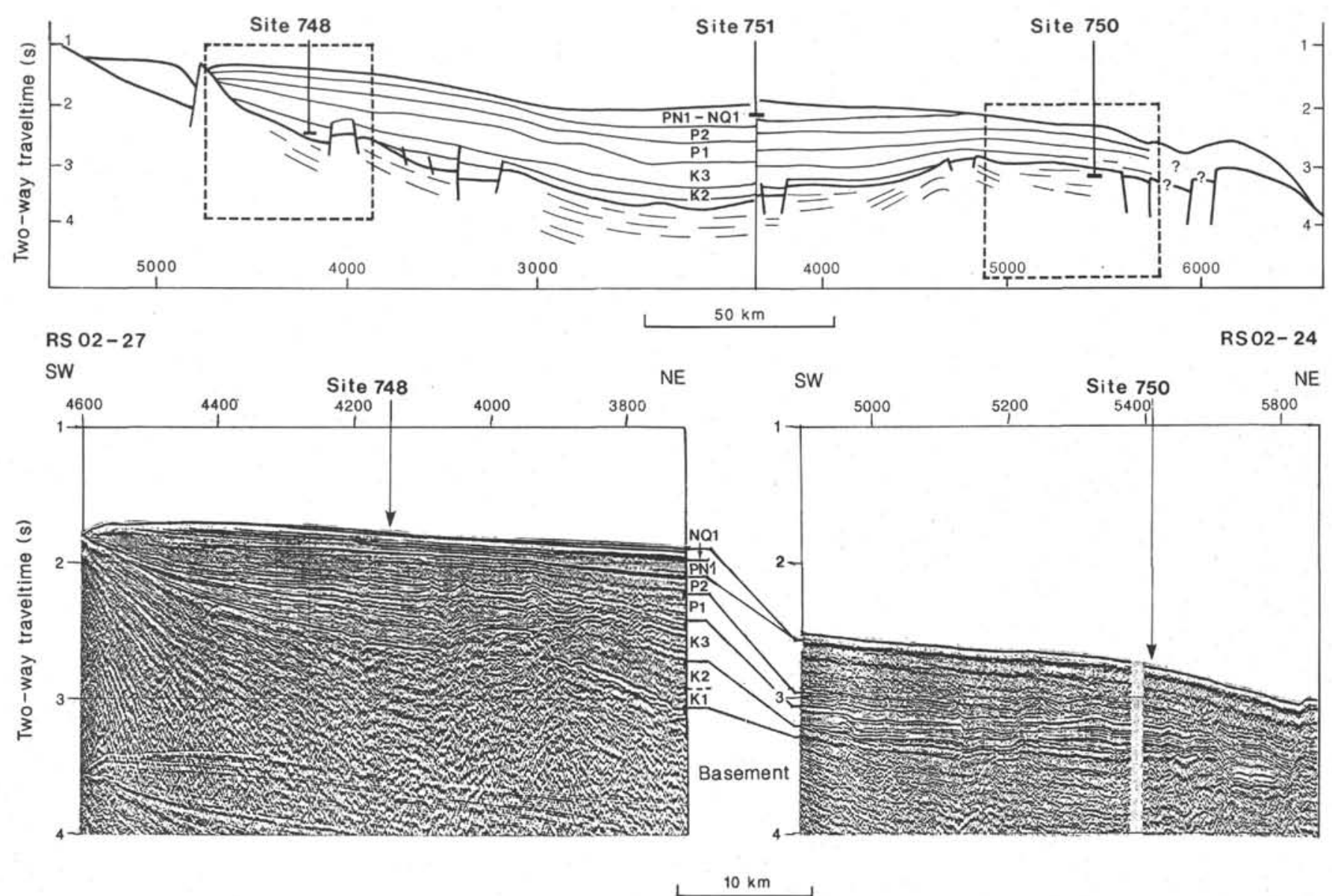

Figure 2. Seismic sections and corresponding line drawing across Sites 748, 750, and 751 in the Raggatt Basin.

where $d=$ density of the rock $\left(\mathrm{kg} / \mathrm{m}^{3}\right)$,

$d f=$ density of the pore fluid $\left(\mathrm{kg} / \mathrm{m}^{3}\right)$, and

$d m=$ density of the matrix $\left(\mathrm{kg} / \mathrm{m}^{3}\right)$.

Both Wyllie's and Raymer's laws were tested at Site 750 for the upper part of the logged interval where porosity is on the order of $50 \%$ (wireline sonic porosity). In this interval we used the available core density measurements. The velocity of the matrix was deduced from a comparison of the wireline logging velocity with the laboratory velocity, as described below. Only Wyllie's law permitted us to calculate reliable synthetic seismograms. We suspect that the poor results given by Raymer's law are related to the use of the discrete core measurements, as already explained for the impedance.

Velocity variations caused by the confining pressure depend on porosity: an increase of pressure causes a decrease of pore volume and thus of water content also. This confining pressure is, in first approximation, directly proportional to depth. The relation between porosity and depth is well established for clays and carbonates (Rubey and Hubbert, 1959; Magara, 1978; Schmoker and Halley, 1982):

$$
\Phi=\Phi_{0} \mathrm{e}^{-K h},
$$

where $\Phi_{0}=$ porosity at atmospheric pressure,

$$
\begin{aligned}
h & =\text { depth }(\mathrm{m}), \text { and } \\
K & =\text { coefficient depending on clay content }\left(\mathrm{m}^{-1}\right) .
\end{aligned}
$$

For other sediments the same law usually applies. The velocity of a formation is approximated by using Wyllie's law and the porosity-depth relation: the velocity of the rock matrix, which is supposed to be constant with depth, is first obtained from the porosity $\Phi_{0}$ and the measured velocity. The fluid is assumed to be water with a velocity of $V f=1500 \mathrm{~m} / \mathrm{s}$. Using Wyllie's law, the velocity at a given depth is related to the matrix velocity, water velocity, and in situ porosity. The in situ porosity is calculated by the exponential law from the measured porosity. At Site 750, along the logged interval, the formation coefficient $K$ is chosen for each sedimentary unit to assure the best fit between the logging velocity and the calculated in situ velocity. Coefficients that made an increase in velocity of more than $20 \%$ of the measured velocity were rejected. Because no logging run were made at Site 748 , the measured velocities were corrected using the procedure describe above with the same coefficients $K$ as those obtained at Site 750 for identical lithologic sequences (Table 2).

\section{Velocity Logs at Sites $\mathbf{7 4 8}$ and $\mathbf{7 5 0}$}

At Site 750 , drilled to a depth of 710 mbsf, recovery averaged between Holes $750 \mathrm{~A}$ and $750 \mathrm{~B}$ is about $7 \%$ for the first $300 \mathrm{~m}$ and $40 \%$ for the deeper part of the holes. In the logged interval (52-450 mbsf), the wireline sonic velocities are about $500 \mathrm{~m} / \mathrm{s}$ higher than the laboratory compressional wave velocity determinations. This discrepancy of $20 \%-30 \%$ agrees well with the experimental velocity measurements made at pressures of 20-30 MPa (Gregory, 1976; Tosaya and Nur, 1982). The coefficients $K$ were determined for the logged interval by fitting corrected velocities with wireline log velocities. For the deepest part of the sedimentary section, where no logging data are available, the coefficients $K$ were adjusted 
Table 2. Coefficients $K$ of the exponential relation between porosity and depth calculated at Site $\mathbf{7 5 0}$ and proposed for Site $\mathbf{7 4 8 .}$

\begin{tabular}{|c|c|c|c|c|c|}
\hline \multicolumn{3}{|c|}{ Site 750} & \multicolumn{3}{|c|}{ Site 748} \\
\hline $\begin{array}{l}\text { Lithologic } \\
\text { unit }\end{array}$ & $\begin{array}{l}\text { Depth } \\
\text { (mbsf) }\end{array}$ & $\begin{array}{c}\text { Coefficient } \\
\times 10^{-4}\end{array}$ & $\begin{array}{l}\text { Lithologic } \\
\text { unit }\end{array}$ & $\begin{array}{l}\text { Depth } \\
\text { (mbsf) }\end{array}$ & $\begin{array}{c}\text { Coefficient } \\
\times 10^{-4}\end{array}$ \\
\hline I and IIA & 0 & 4 & I and IIA & 0 & 4 \\
\hline IIB & 320 & 2 & IIB & 185 & 4 \\
\hline IIIA & 356 & 2 & IIIA & 385 & 2 \\
\hline IIIB & 450 & 2 & IIIB & 692 & 1 \\
\hline IIIC and IV & 600 & I & & & \\
\hline Basalt & $675-710$ & 0 & Basalt & $898-935$ & 0 \\
\hline
\end{tabular}

Note: $K$ in $\mathrm{m}^{-1}$.

to obtain a continuous corrected velocity curve between lithologic Subunits IIIA and IIIB. The coefficients $K$ for lithologic Subunits IIIC and Unit IV were chosen to account for the high velocity gradients at 596-620 mbsf and at the sediment-basalt contact ( $673 \mathrm{mbsf}$ ), which necessarily corresponds to the seismic reflectors located at 0.56 and $0.62 \mathrm{~s}$ two-way traveltime (twt) on the seismic profile. Although the subjectivity of the proposed method is obvious, the derived velocities and coefficients $K$ are not aberrant.

The formation coefficients $K$ agree well with other published values. Schmoker and Halley (1982) examined the porosity-depth relation for carbonate, dolomite, and limestone and found coefficients of 0.0004 (1/2498), 0.0002 (1/4618), and 0.001 (1/1929), respectively. Sclater and Christie (1980) studied sediments from the central North Sea and determined coefficients of 0.00051 for shale, 0.00027 for sand, 0.00071 for chalk, and 0.00039 for shaley sand. Corrections for the basalt velocity values are not needed as the measured porosity is so small that the variation of velocity with depth is negligible.

To calculate the synthetic seismogram, we used a velocity log based on wireline logging velocities for the logged interval and on corrected velocities for the unlogged interval. The velocity log was interpolated with a cubic spline operator and was resampled at a constant sample interval to compute the synthetic seismogram.

At Site 748, drilled to a depth of $935 \mathrm{mbsf}$, the average recovery rate among Holes $748 \mathrm{~A}, 748 \mathrm{~B}$, and $748 \mathrm{C}$ is about $33 \%$. No logging run was made at this site; the velocity $\log$ is entirely built from corrected core velocity determinations. At this site, the coefficient $K$ used for each lithologic units was taken from Site 750 . The synthetic seismogram is based only on the corrected velocities that were interpolated as already explained for Site 750 .

\section{CORRELATION WITH SEISMIC SEQUENCES}

We used the computed synthetic seismogram to correlate the seismic sequences with the ODP stratigraphic columns at Site 748 (Fig. 3 and Table 3) and Site 750 (Fig. 4 and Table 3). Based upon these correlations and a critical seismic strati-

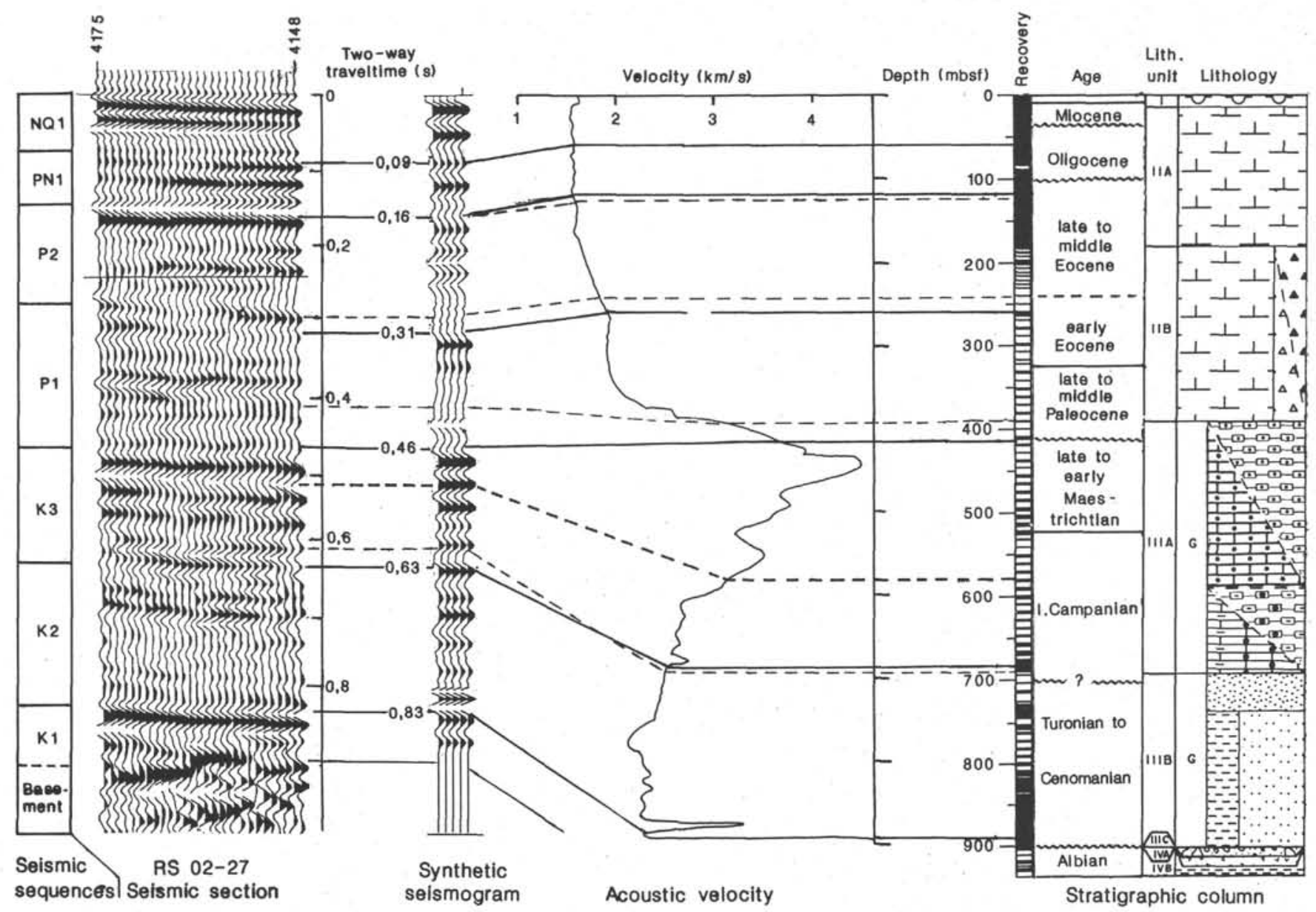

Figure 3. Depth-time correlation for Site 748. The solid lines refer to the correlations proposed in this paper; the dashed lines refer to the correlations made by the Leg 120 scientists ("Site 748" chapter, in Schlich, Wise, et al., 1989) when they are different. 


\section{B. FRITSCH ET AL.}

Table 3. Correlation between seismic sequences, depths, and ages at Sites 748 and $\mathbf{7 5 0}$.

\begin{tabular}{|c|c|c|c|c|c|c|c|c|}
\hline \multirow[b]{3}{*}{ Sequence } & \multicolumn{4}{|c|}{ Site 748} & \multicolumn{4}{|c|}{ Site 750} \\
\hline & \multicolumn{2}{|c|}{ Upper limit } & \multirow[b]{2}{*}{$\begin{array}{l}\text { Thickness } \\
\text { (m) }\end{array}$} & \multirow[b]{2}{*}{ Age (Ma) } & \multicolumn{2}{|c|}{ Upper limit } & \multirow[b]{2}{*}{$\begin{array}{l}\text { Thickness } \\
\text { (m) }\end{array}$} & \multirow[b]{2}{*}{ Age (Ma) } \\
\hline & (s) & $\begin{array}{l}\text { Depth } \\
\text { (mbsf) }\end{array}$ & & & (s) & $\begin{array}{l}\text { Depth } \\
\text { (mbsf) }\end{array}$ & & \\
\hline NQ1 & 0 & 0 & 70 & Miocene & & & & \\
\hline PN1 & 0.09 & 70 & 45 & Oligocene & & & & \\
\hline $\mathrm{P} 2$ & 0.16 & 115 & 145 & $\begin{array}{l}\text { middle Eocene } \\
\text { (54/52 to } 38 \text { ) }\end{array}$ & 0.0 & 0 & 220 & $\begin{array}{l}\text { middle Eocene } \\
(50 ? \text { to } 42)\end{array}$ \\
\hline P1 & 0.31 & 260 & 156 & $\begin{array}{l}\text { early Paleocene to } \\
\text { middle Eocene } \\
\text { (66 to } 54 / 52)\end{array}$ & 0.24 & 220 & 135 & $\begin{array}{l}\text { middle Paleocene to } \\
\text { middle Eocene } \\
\text { (66 to 50?) }\end{array}$ \\
\hline K3 & 0.46 & 416 & 269 & $\begin{array}{l}\text { late Campanian to late } \\
\text { Maestrichtian } \\
\text { (84/75 to 66) }\end{array}$ & 0.37 & 355 & 245 & $\begin{array}{l}\text { early Santonian to late } \\
\text { Maestrichtian } \\
\text { (88 to 66) }\end{array}$ \\
\hline K2 & 0.63 & 685 & 215 & $\begin{array}{l}\text { Cenomanian to } \\
\text { Turonian }\end{array}$ & 0.56 & 600 & 75 & $\begin{array}{l}\text { early Albian to } \\
\text { Coniacian }\end{array}$ \\
\hline K1 & 0.83 & 900 & $90-180$ & Albian & & & & \\
\hline Basement & 0.92 & & & $?$ & 0.62 & 675 & & $\begin{array}{l}\text { Albian } \\
\text { (110) }\end{array}$ \\
\hline
\end{tabular}

graphic analysis of MCS profiles, we defined the evolution of the Raggatt Basin more precisely. Seven seismic stratigraphic sequences have been identified in the Raggatt Basin (Schlich, Wise, et al., 1989; Coffin et al., 1990).

The oldest sequence, $\mathrm{K} 1$, is confined to the deepest part of the basin. Sequences K1 and K2 filled the topographic lows, onlap the pre-existing basement complex, and lie unconformably under Sequence K3. Sequence K3 disappears to the southwest by toplap below an erosional surface and is characterized by chaotic structures to the west. These chaotic structures appear to develop in the entire Sequence K3 and are covered by Sequence P1. Sequences P1 and P2 become progressively thinner to the southwest and disappear unconformably under the overlaying sequence. A major unconformity separates Sequence P2 from the two uppermost Sequences PN1 and NQ1. These two sequences are only observed in the central and shallower part of the basin and are truncated in all directions by erosion and/or nondeposition.

\section{Site 748}

The reflector at $0.83 \mathrm{~s}$ twt $(900 \mathrm{mbsf})$ is the deepest reflector observed on the synthetic seismogram. The basement reflector was observed at $0.92 \mathrm{~s}$ twt by the Leg 120 scientists (Schlich, Wise, et al., 1989, "Site 748" chapter) and was not reached by drilling. Lithologic Subunit IVB lies below 900 mbsf and consists of claystone and altered basalt. No physical property measurements were made on the core recovered at these depths. If we assume a velocity of $2000-4000 \mathrm{~m} / \mathrm{s}$ for this formation, the basement reflector would be at a depth of 90-180 m below the top of Subunit IVB (i.e., 990-1080 mbsf).

The reflector at $0.83 \mathrm{~s}$ twt $(900 \mathrm{mbsf})$ correlates with the K1/K2 boundary and with the boundary between Subunits IIIC and IVA (Schlich, Wise, et al., 1989, "Site 748" chapter). It is correlated, at Site 748, with the top of a 3-m-thick altered basalt flow. Seismic Sequence K1, deposited presumably during Albian time, consists of claystone and very altered basalt. During this time, the site was probably subaerial or at shallow depths.

The $\mathrm{K} 2 / \mathrm{K} 3$ boundary was correlated by the Leg 120 scientists (Schlich, Wise, et al., 1989, "'Site 748" chapter) with a reflector at $0.61 \mathrm{~s}$ twt $(692 \mathrm{mbsf})$ and was associated with the top of Subunit IIIB. Using the synthetic seismogram, this reflector corresponds now to a depth of $660 \mathrm{mbsf}$, and we found that the $\mathrm{K} 2 / \mathrm{K} 3$ reflector is one phase below, at $0.63 \mathrm{~s}$ twt (685 mbsf). Seismic Sequence K2, $215 \mathrm{~m}$ thick, is dated from late Cenomanian to early Turonian and correlates with lithologic Subunit IIIB. The sediments are glauconitic and were deposited at shallow depths $(50-200 \mathrm{~m})$.

The K3/P1 boundary was located at $0.41 \mathrm{~s}$ twt ( $389 \mathrm{mbsf})$ by the Leg 120 scientists (Schlich, Wise, et al., 1989, "Site 748" chapter) and corresponds to a low-to-medium amplitude reflector. This reflector was associated on board with the top of Subunit IIIA at 389 mbsf, which is marked by a lithologic change but no velocity contrast. Two hiatuses are identified at 418-416 and 408-406 mbsf. They represent a duration of 2 m.y. (middle to late Maestrichtian, from 69 to $67 \mathrm{Ma}$ ) and 6 m.y. (Danian, from 67 to $61 \mathrm{Ma}$ ), respectively. These hiatuses may be explained by uplift of the plateau and emergence of the site perhaps in conjunction with the short-term sea-level variation between 60 and $58 \mathrm{Ma}$ described by Haq et al. (1987). The two hiatuses were also clearly observed at Site 747 in the central part of the Kerguelen Plateau (72-66 and 62-58 Ma). At Site 750 the sedimentation rate changes abruptly 66 m.y. ago. Therefore, we suggest that the upper limit of Sequence K3 be placed, at Site 748 , at the late Maestrichtian to early Paleocene boundary $(66 \mathrm{Ma})$. Both hiatuses correlate very well on the synthetic seismogram with a complex highamplitude reflector at $0.46 \mathrm{~s}$ twt (416 mbsf). Sequence K3, 270 $\mathrm{m}$ thick, was deposited in outer shelf conditions for the upper part of the sequence and in inner shelf conditions at very shallow water depths for the lower part; this sequence is dated from late Campanian to late Maestrichtian. The entire sedimentary section has a high glauconitic content. Sequence K3 contains many calcareous planktonic fossils, whereas Sequence K2 is almost barren. About $10-60 \mathrm{~km}$ eastward of Site 748 , Sequence K3 shows many chaotic structures, associated in some places with faults, that could correspond to volcanoes or carbonate mounds (Coffin et al., 1990). At Site 748, Sequence K3 is characterized by a high content of carbonate and shallow water deposition. The chaotic structures are linked together by parallel reflectors and rest upon undisturbed reflectors (Fig. 5). These observations are strong arguments for the carbonate mounds hypothesis. The unconformity at the top of Sequence $\mathrm{K} 3$ marks the top of the carbonate mounds. Lithologic Subunit IIIA, $303 \mathrm{~m}$ thick, extends $20 \mathrm{~m}$ above the K3/P1 boundary.

The reflector at $0.29 \mathrm{~s}$ twt $(243 \mathrm{mbs})$ was defined as the P1/P2 boundary (Schlich, Wise, et al., 1989, "Site 748" chapter). This reflector correlates neither with a lithologic change nor with a velocity contrast. We propose to locate the $\mathrm{P} 1 / \mathrm{P} 2$ boundary one phase below at $0.31 \mathrm{~s}$ twt ( $260 \mathrm{mbsf})$. At this depth, the velocity slowly decreases upward, as sediment 


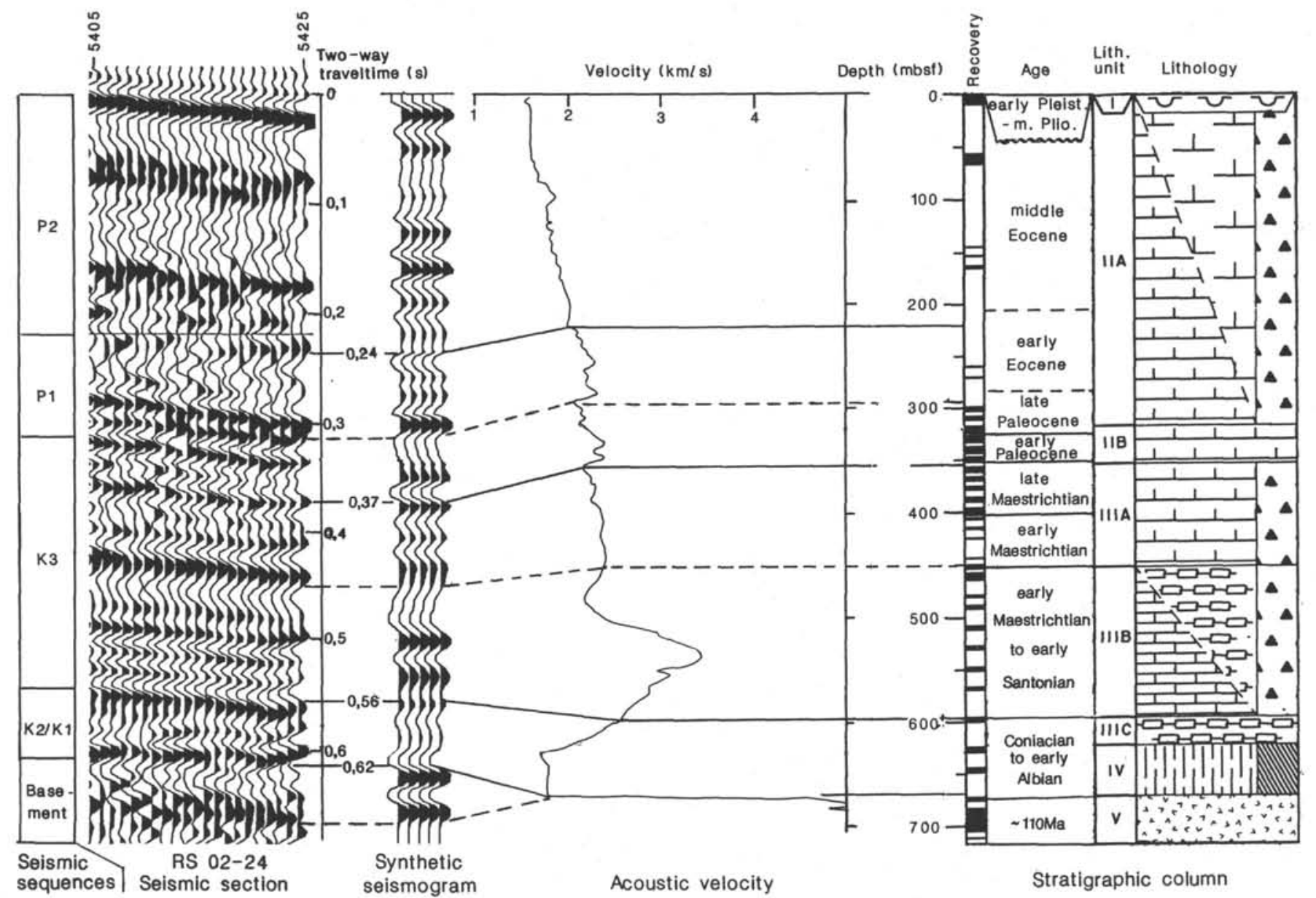

Figure 4. Depth-time correlation for Site 750. The solid lines refer to the correlations proposed in this paper; the dashed lines refer to the correlations made by the Leg 120 scientists (Schlich, Wise, et al., 1989, "Site 750" chapter) when they are different.

becomes less consolidated; moreover, at this level, the sedimentation rate curve shows an inflection between biostratigraphic datums F11 and F10 (Schlich, Wise, et al., 1989, "Site 748" chapter, p. 206). Despite the lack of reliable dates between 55 and $48 \mathrm{Ma}$, this change of sedimentation rate can be dated at 54-52 Ma. Thus, the 156-m-thick Sequence P1 was deposited between early Paleocene (66 Ma) and earlymiddle Eocene (54-52 Ma) times. The lowermost $30 \mathrm{~m}$ of sediments of Sequence P1 are pelagic ooze and chert with a small amount of glauconite. This indicates a quick subsidence, which deepened the seafloor from 200 to $1000 \mathrm{~m}(150 \mathrm{~m} / \mathrm{m}$.y.). Paleodepths of $500-2000 \mathrm{~m}$ characterize the younger sediments of Sequence P1.

The P2/PN1 reflector, at $0.16 \mathrm{~s}$ twt is located at $115 \mathrm{mbsf}$, slightly above the depth proposed by the Leg 120 scientists (Schlich, Wise, et al., 1989, "Site 748" chapter). This highamplitude reflector can be correlated with a small downward increase in the velocity at 115 mbsf that occurs $10 \mathrm{~m}$ below a $2-\mathrm{m} . \mathrm{y}$. hiatus dated as late Eocene $(38 \mathrm{Ma})$. Sequence P2 is 54-52 to $38 \mathrm{~m}$.y. old (Eocene) and is $145 \mathrm{~m}$ thick. During this time span, sediment was deposited under 500-2000 m water depths. In this sequence, the velocity increases uniformly with depth from 1600 to $1900 \mathrm{~m} / \mathrm{s}$.

The reflector associated with the PN1/NQ1 boundary is located at $0.09 \mathrm{~s}$ twt $(70 \mathrm{mbsf})$. Sequence PN1 consists of $45 \mathrm{~m}$ of nannofossil oozes deposited during Oligocene time (Schlich, Wise, et al., 1989, "Site 748" chapter).
Sequence NQ1, from $0.09 \mathrm{~s}$ twt $(70 \mathrm{mbsf})$ to the seafloor reflector, is dated as Miocene. It is characterized by two hiatuses, the first one of 5-m.y. duration, from 17 to $12 \mathrm{Ma}$, at 40 mbsf; the second one of 3-m.y. duration, from 8 to $5 \mathrm{Ma}$, at 11 mbsf. Sequence NQ1 consists of nannofossil ooze covered by diatom ooze (Schlich, Wise, et al., 1989, "Site 748"' chapter). The Pleistocene-Pliocene sediment layer (10-13 m thick) is too thin to be seen on the seismic section.

\section{Site $\mathbf{7 5 0}$}

The reflector at $0.62 \mathrm{~s}$ twt $(675 \mathrm{mbs})$ corresponds to the basaltic basement (Fig. 4 and Table 3 ). The reflector at $0.69 \mathrm{~s}$ twt previously identified with the basement (Schlich, Wise, et al., 1989, "Site 750" chapter) is, in fact, an intra-basement reflector located about $100 \mathrm{~m}$ below the bottom of the hole. The basement consists of moderate to highly altered basalt flows of Albian age (110 Ma).

The reflector at $0.56 \mathrm{~s}$ twt $(600 \mathrm{mbsf})$ corresponds to the $\mathrm{K} 2 / \mathrm{K} 3$ boundary and to the top of lithologic Subunit IIIC. This reflector interferes with a reflector at $0.58 \mathrm{~s}$ twt $(620 \mathrm{mbsf})$ that is associated with the top of Unit IV. The $\mathrm{K} 2 / \mathrm{K} 3$ boundary was associated by the Leg 120 scientists (Schlich, Wise, et al., 1989 , "Site 750 " chapter) with a reflector at $0.59 \mathrm{~s}$ twt (595 mbsf). The corresponding sequence is early Albian at the base and was deposited in a subaqueous or subaerial environment with a terrestrial component up to the Coniacian. This time span corresponds to Sequences K1-K2. 
WSW

2600

2700

2800

2900

3000

3100

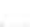

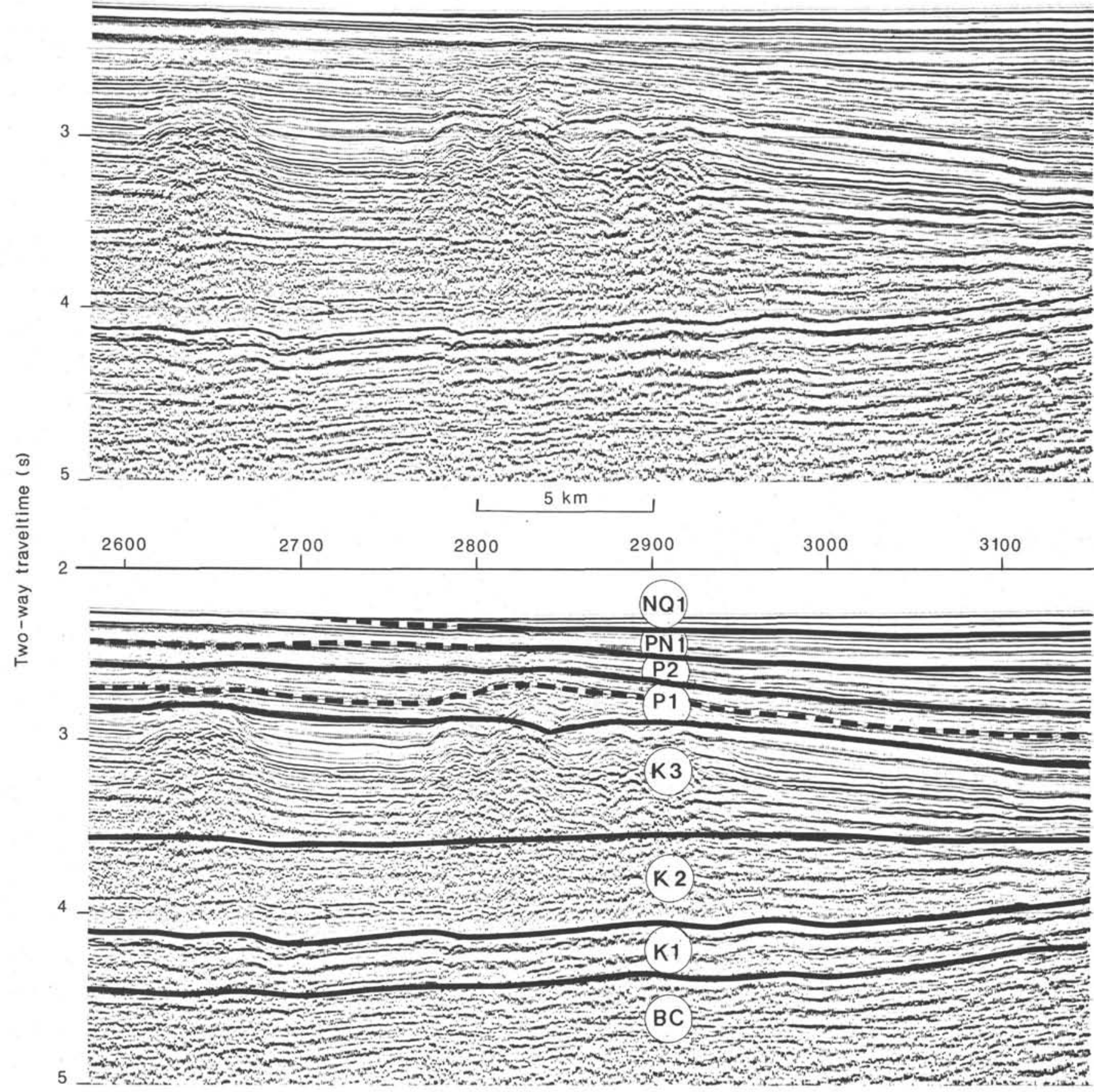

Figure 5. Carbonate mounds on seismic section RS 02-24 in the western part of the Raggatt Basin. The seismic sequences as identified by Schlich, Wise, et al. (1989) and Coffin et al. (1990) are shown in the figure. BC refers to the basement.

The K3/P1 reflector at $0.46 \mathrm{~s}$ twt $(450 \mathrm{mbsf})$ was dated by the Leg 120 scientists as early Maestrichtian (Schlich, Wise, et al., 1989, "Site 750" chapter); this age disagrees by about 10 m.y. with the middle Paleocene age of the top of Sequence K3 at Site 748. A reinterpretation of MCS Profile RS 02-24 places the K3/P1 reflector at $0.37 \mathrm{~s}$ twt $(355 \mathrm{mbsf})$. The traveltime difference $(0.09 \mathrm{~s}$ twt) with the previous interpretation could be related to a fault system observed on MCS Profile RS 02-24 at shot point $4800,30 \mathrm{~km}$ westward of Site 750 . We now think that the K3/P1 reflector, dated as late Maestrichtian (66 Ma), corresponds to the top of lithologic Subunit IIIA. The 245-mthick K3 Sequence, deposited from early Santonian to late Maestrichtian times, encompasses lithologic Subunits IIIC, IIIB, and IIIA. The deepest sediment of Sequence K3 is the 
oldest pelagic sediment at Site 750 . From the bottom to the top of Sequence K3, the depositional environment changed from an outer continental shelf to a continental slope environment.

The P1/P2 reflector located at $0.31 \mathrm{~s}$ twt $(290 \mathrm{mbsf})$ was dated as early Paleocene-late Eocene (Schlich, Wise, et al., 1989, "Site 750" chapter). This age disagrees with the middle Eocene age found at Site 748. The new interpretation of MCS Profile RS 02-24 shows that the $\mathrm{P} 1 / \mathrm{P} 2$ reflector could be placed at $0.24 \mathrm{~s}$ twt ( $220 \mathrm{mbsf})$ and, thus, could be dated as middle Eocene (no core was recovered between 143 and 259 mbsf). This depth of $220 \mathrm{mbsf}$ corresponds to the top of $\log$ Unit 2, where an increase with depth of the sonic logging velocity was observed in relation to an increase of sediment compaction. Sequence P1, $135 \mathrm{~m}$ thick, is of early Paleocene to middle Eocene age and corresponds to lithologic Subunit IIB and to the lower part of Subunit IIA.

Sequence P2, $220 \mathrm{~m}$ thick, is dated as middle Eocene. One meter of Pleistocene-Pliocene sediment unconformably overlies Sequence P2. The hiatus at the top of P2 extends from 42 to $5 \mathrm{Ma}$.

\section{DISCUSSION}

The basalts cored in the Raggatt Basin at Sites 748, 749, and 750 are slightly to highly altered flows, up to $5 \mathrm{~m}$ thick, brecciated basalts, and basalt pebbles. Some sediments are interbedded between the flows at Site 748. Basalts at Sites 749 ( $48 \mathrm{~m}$ cored) and 750 ( $34 \mathrm{~m}$ cored) were erupted close to sea level before the middle Albian, $110 \mathrm{~m} . \mathrm{y}$. ago (Whitechurch et al., this volume). These basalts are transitional in composition between typical Indian Ocean mid-ocean ridge basalts and normal oceanic-island basalts. Basalt at Site $748(4.5 \mathrm{~m}$ recovered) is younger ( $80 \mathrm{Ma}$; Whitechurch et al., this volume) and has compositional characteristics similar to intraplate, oceanic-island alkaline basalt; this basalt does not correspond to basement, as previously shown, but lies $90-180$ $\mathrm{m}$ above the true basement.

The basement, as observed on the MCS profiles, has been interpreted to be the result of successive volcanic flows in subaerial conditions (Schaming and Rotstein, 1990). The time span between each volcanic episode appears to have been long enough to allow for alteration and erosion. In some places, it is almost impossible to distinguish the basement from Sequence $\mathrm{K} 1$; however, interval velocities of 4.8-5.5 $\mathrm{km} / \mathrm{s}$ have been derived from MCS data for the basement and of $3.5-4.8 \mathrm{~km} / \mathrm{s}$ for Sequence K1. Where well defined, the top of the basement corresponds to a high-amplitude and highcontinuity reflector affected by toplap (erosional surface).

Site 748 is located on the western flank of the basement synform associated with the Raggatt Basin (Rotstein et al., 1990). Site 750 lies $20 \mathrm{~km}$ eastward of a basement ridge, on the eastern side of the Raggatt Basin (Rotstein et al., 1990). At this location more than $1 \mathrm{~s}$ twt $(2.5 \mathrm{~km}$, assuming a velocity of 5 $\mathrm{km} / \mathrm{s}$ ) of internal reflectors were observed within the basement (Fig. 2). In the central part of the synform, these intrabasement reflectors are almost horizontal. On each side of the synform, they display a $5^{\circ}-8^{\circ}$ dip along northeast-southwest profiles. The true dip can only be calculated at three MCS profile intersections close to Site 751: the mean direction is $\mathrm{N} 70^{\circ} \mathrm{W}$. At Site 748 , the intra-basement reflectors dip $1.7^{\circ}-$ $2.8^{\circ}$ eastward along Profile RS 02-27 and extend downward to $0.7 \mathrm{~s}$ twt $(1.8 \mathrm{~km}$, assuming a velocity of $5 \mathrm{~km} / \mathrm{s})$.

The basement was eroded after emplacement. Sequences $\mathrm{K} 1$ and $\mathrm{K} 2$ were deposited in subaerial or shallow-water conditions and onlapped the western flank of the basement synform. Sequence $\mathrm{K} 2$ is characterized by a very low interval velocity $(2.0-2.3 \mathrm{~km} / \mathrm{s})$ compared with the velocities of Sequences K1 $(3.5-4.8 \mathrm{~km} / \mathrm{s})$ and $\mathrm{K} 3(2.8-3.2 \mathrm{~km} / \mathrm{s})$. The two sequences are very thin close to Site 750 (about $75 \mathrm{~m}$ ) and almost disappear over the basement ridge observed at shot point 4800 (Fig. 2). In the vicinity of Site 750 , chaotic reflectors affecting Sequences $\mathrm{K} 1$ and $\mathrm{K} 2$ indicate a highenergy-depositional environment or an alternation of deposition and erosion. The eastern part of the basin remains very close to sea level until about the end of the Coniacian (end of deposition of Sequence K2). Sequence K2 lies unconformably under Sequence K3; erosional features were observed near the eastern flank of the synform. This erosion is confirmed by the clayey siltstones cored in the upper part of Sequence K2 at Site 750 (Core 120-750B-12W); it occurred before the deposition of Sequence K3, at the beginning of the Santonian (roughly $88 \mathrm{Ma}$ ) and is followed by subsidence to a depth of at least $200 \mathrm{~m}$, which is the lower limit of the abundant glauconite formation.

Sequence K3, deposited between 88 and $66 \mathrm{Ma}$, appears very different between the eastern Site 750 and the western Site 748. Pelagic sediment, evolving from the outer continental shelf to the continental slope, was found at Site 750 , whereas sediment of constant shallow-water depths was observed at Site 748 .

The western part of the basin is characterized by carbonate mounds located 10-70 km east of Site 748. The apparent limit of the mounds follows a north-south direction and seems to extend to the chaotic configurations observed to the west of the central part of the Kerguelen Plateau. The carbonate mounds appear to be related to the $77^{\circ} \mathrm{E}$ Graben and are observed on its eastern flank. The top of the carbonate mounds are characterized by high-amplitude and low-continuity reflectors; they are much more chaotic at this level than below, suggesting emergence of these structures. After this emergence, the western part of the basin subsided rapidly to more than $1000 \mathrm{~m}$ below sea level, at a rate of $150 \mathrm{~m} / \mathrm{m}$.y. (Schlich, Wise, et al., 1989, "Site 748" chapter), and reached the same depth as the eastern part of the plateau. The depocenter of the Raggatt Basin was shifted to the east after deposition of the cretaceous sediments.

Sequence P1 was deposited over the entire Raggatt Basin between early Paleocene (66 Ma) and middle Eocene times below 1000-2000 m water depths. The upper boundary of Sequence P1 corresponds to a change in the rate of sedimentation documented at both sites at 54-52 Ma. The upper boundary of Sequence P2 is defined by toplap in the center of the basin and corresponds to a hiatus at $38 \mathrm{Ma}$ at Site 748 and a hiatus at $42 \mathrm{Ma}$ at Site 750 .

Oligocene and Miocene sediments are not present at Site 750 , in contrast to Sites 748 and 751 (Schlich, Wise, et al., 1989 , "Site 748," "Site 750," and "Site 751"' chapters). The two latter sites show two major hiatuses: the first one, between 17 and $12 \mathrm{Ma}$, is only recorded in the Raggatt Basin, whereas the second one, between 8 and $5 \mathrm{Ma}$, is recorded on the entire SKP and also at Site 747 in the central part of the Kerguelen Plateau (Schlich, Wise, et al., 1989, "Site 747" chapter).

\section{CONCLUSIONS}

The correlation of seismic sections with ODP drilling results (Figs. 4 and 5) and a reinterpretation of composite MCS profiles between Sites 748, 750, and 751 (Fig. 2) provide new insight on the evolution of the Southern Kerguelen Plateau (Fig. 6).

Before or during Albian time (110 Ma), thick basalt flows formed the Southern Kerguelen Plateau during successive volcanic episodes. As a result of the volcanic activity, basement synforms and basement ridges shaped the plateau. At this time, much of the plateau was above sea level (Fig. 6A). 

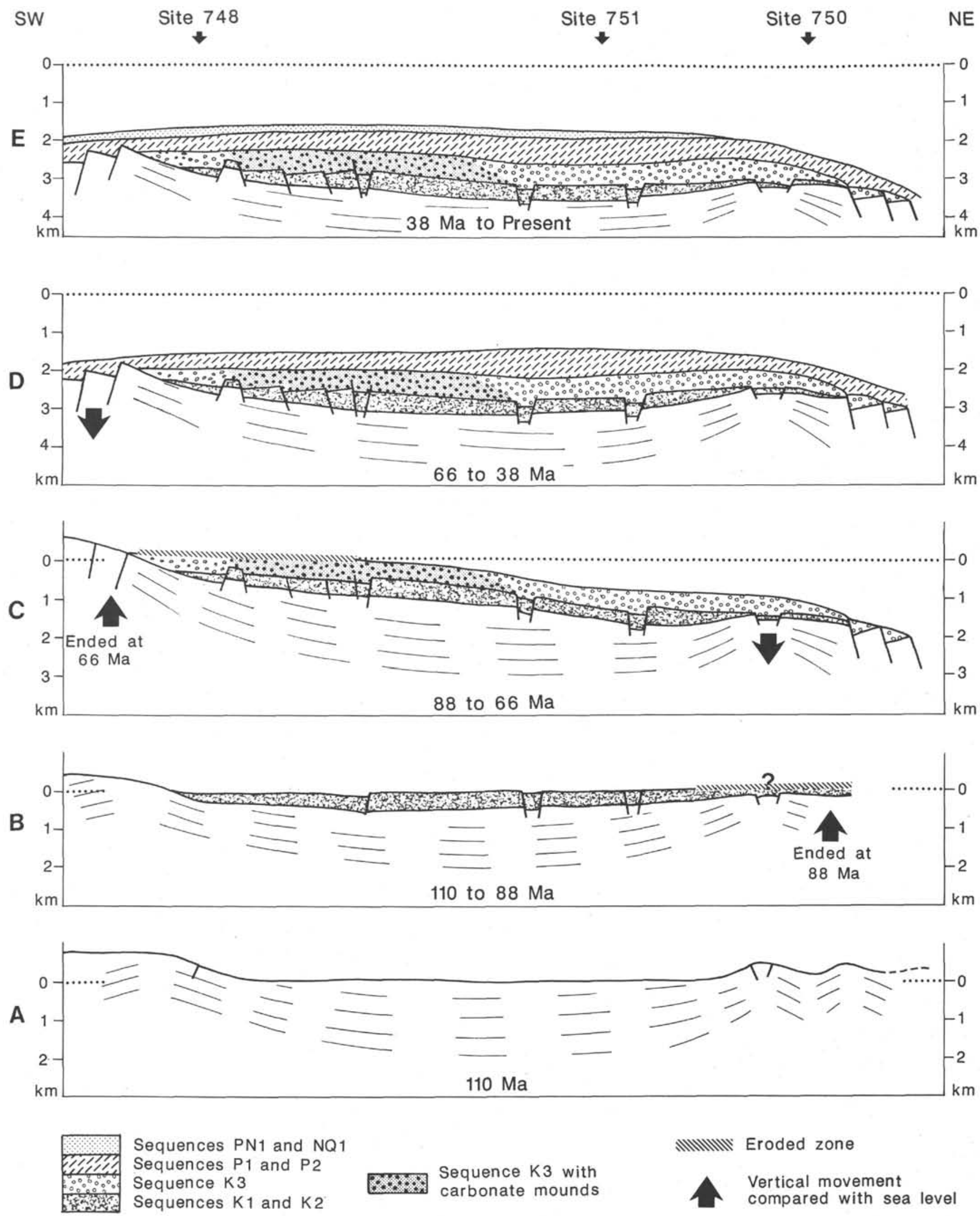
$6 \%$ Sequence K3 with
NIIII) Eroded zone

Vertical movement compared with sea level

Figure 6. Schematic representation of the evolution of the Raggatt Basin. 
Between 110 and $88 \mathrm{Ma}$, the basement was strongly eroded, and sediment filled the Raggatt Basin basement synform and covered the eastern basement ridge. Gradual and probably thermal subsidence affected the entire Raggatt $\mathrm{Ba}$ sin. Continental-type sedimentation $(\mathrm{K} 1-\mathrm{K} 2)$ prevailed during this time span. At the beginning of the Turonian, the eastern Raggatt Basin was uplifted in association with faulting (Fig. 6B). The uplift was followed by subsidence and can be interpreted as the result of extension along a northwestsoutheast direction that will give rise to the eastern SKP margin.

After this tectonic event, the eastern part of the SKP subsided and pelagic sediment was deposited, whereas to the west the sedimentation regime remained at shallow water depths (K3). During the Campanian and the Maestrichtian, carbonate mounds were developed in the western part of the Raggatt Basin, suggesting a very slow subsidence. Later, the basin was uplifted $(66 \mathrm{Ma})$ in association with the north-south tectonic event that formed the $77^{\circ} \mathrm{E}$ Graben. The western part of the Raggatt Basin represents one of the rift flanks associated with the $77^{\circ} \mathrm{E}$ Graben (Fig. 6C).

During the Paleocene, the western part of the Raggatt Basin subsided rapidly to $1000 \mathrm{~m}$ water depths. From the late Paleocene ( $58 \mathrm{Ma}$ ) to about $40 \mathrm{Ma}$, a slow thermal subsidence affected the entire SKP, which reached a depth of 1000-2000 $\mathrm{m}$ (P1). At 54-52 Ma, the sedimentation rate changed abruptly over most of the Raggatt Basin (P2) (Fig. 6D).

At $38 \mathrm{Ma}$, an erosional event was observed on the entire plateau. This event is related to the separation by seafloor spreading of the Kerguelen Plateau-Labuan Basin and Broken Ridge-Diamantina Zone dated at 45-42 Ma by Munschy and Schlich (1987). No sediment was deposited in the eastern part of the basin between middle Eocene and middle Pliocene times. In the central and western parts of the basin, Oligocene and Miocene (PN1 and NQ1) sediments are present, and two erosional events were observed in the Miocene between 17 and $12 \mathrm{Ma}$ and between 8 and $5 \mathrm{Ma}$ (Fig. 6E).

\section{ACKNOWLEDGMENTS}

R. Schlich, M. Munschy, and M. F. Coffin thank the Ocean Drilling Program for inviting them to participate on Leg 120 on board the JOIDES Resolution. The authors thank E. Barbu, A. Cooper, R. E. Houtz, and S. W. Wise, Jr., for critical reviews and comments. We also thank $\mathrm{M}$. Blanck for drafting the figures. We are grateful to Territoire des Terres Australes et Antarctiques Françaises for their support on board Marion Dufresne (Cruise MD47) and to the Australian Bureau of Mineral Resources for making available to us Rig Seismic data. This work was supported by the Centre National de la Recherche Scientifique (ODP-France). M. F. Coffin publishes by permission of the Director of the Bureau of Mineral Resources.

\section{REFERENCES}

Aubry, M.-P., Berggren, W. A., Kent, D. V., Flynn, J. J., Klitgord, K. D., Obradovich, J. D., and Prothero, D. R., 1988. Paleogene geochronology: an integrated approach. Paleoceanography, 3:707-742.

Badley, M. E., 1985. Data preparation and preliminary studies. In Badley, M. E. (Ed.), Practical Seismic Interpretation: Boston (Int. Human Resources Dev. Corp.), 6:157-186.

Barron, J., Larsen, B., et al., 1989. Proc. ODP, Init. Repts., 119: College Station, TX (Ocean Drilling Program).

Berggren, W. A., Kent, D. V., and Flynn, J. J., 1985a. Jurassic to Paleogene: Part 2. Paleogene geochronology and chronostratigraphy. In Snelling, N. J. (Ed.), The Chronology of the Geological Record. Geol. Soc. London Mem., 10:141-195.
Berggren, W. A., Kent, D. V., Flynn, J. J., and Van Couvering, J. A., 1985b. Cenozoic geochronology. Geol. Soc. Am. Bull., 96:14071418.

Berggren, W. A., Kent, D. V., and Van Couvering, J. A., 1985. The Neogene: Part 2. Neogene geochronology and chronostratigraphy. In Snelling, N. J. (Ed.), The Chronology of the Geological Record. Geol. Soc. London Mem., 10:211-260.

Coffin, M. F., Davies, H. L., and Haxby, W. F., 1986. Structure of the Kerguelen Plateau province from SEASAT altimetry and seismic reflection data. Nature, 324:134-136.

Coffin, M. F., Munschy, M., Colwell, J. B., Schlich, R., Davies, H. L., and Li, Z. G., 1990. Seismic stratigraphy of the Raggatt Basin, Southern Kerguelen Plateau: tectonic and paleoceanographic implications. Geol. Soc. Am. Bull., 102:563-579.

Colwell, J. B., Coffin, M. F., Pigram, C. J., Davies, H. L., Stagg, H.M.J., and Hill, P. J., 1988. Seismic stratigraphy and evolution of the Raggatt Basin, southern Kerguelen Plateau. Mar. Pet. Geol., 5:75-81.

Gregory, A. R., 1976. Fluid saturation effects on dynamic elastic properties of sedimentary rock. Geophysics, 41:895-921.

Guglielmi, M., 1982. Etude géophysique du plateau de Kerguelen [Diplôme d'ingénieur géophysicien]. Inst. de Physique du Globe, Univ. Louis Pasteur, Strasbourg, France.

Haq, B. u., Hardenbol, J., and Vail, P. R., 1987. Chronology of fluctuating sea levels since the Triassic. Science, 235:1156-1166.

Houtz, R. E., Hayes, D. E., and Markl, R. G., 1977. Kerguelen Plateau bathymetry, sediment distribution and crustal structure. Mar. Geol., 25:95-130.

Kent, D. V., and Gradstein, F. M., 1985. A Cretaceous and Jurassic geochronology. Geol. Soc. Am. Bull., 96:1419-1427.

LeClaire, L., Bassias, Y., Denis-Clochiatti, M., Davies, H. L., Gautier, I., Gensous, B., Giannesini, P.-J., Patriat, P., Ségoufin, J., Tesson, M., and Wannesson, J., 1987a. Lower Cretaceous basalt and sediments from the Kerguelen Plateau. Geo-Mar. Lett., $7: 169-176$.

Leclaire, L., Denis-Clocchiatti, M., Davies, H. L., Gautier, I., Gensous, B., Giannesini, P. J., Morand, F., Patriat, P., Ségoufin, J., Tesson, M., and Wannesson, J., 1987b. Nature et âge du plateau de Kerguelen-Heard, secteur sud. Résultats préliminaires de la campagne "N.A.S.K.A.-MD48." C.R. Acad. Sci., Ser. 2, 304:23-28.

Magara, K., 1978. Compaction and Fluid Migration: Practical Petroleum Geology: New York (Elsevier).

Munschy, M., and Schlich, R., 1987. Structure and evolution of the Kerguelen Plateau (Indian Ocean) deduced from seismic stratigraphy studies. Mar. Geol., 76:131-152.

Nafe, H. E., and Drake, C. L., 1963. Physical properties of marine sediments. In Hill, M. N. (Ed.), The Sea (Vol. 3): New York (Wiley-Interscience), 794-815.

Nur, A., and Murphy, W., 1981. Wave velocities and attenuation in porous media with fluid. Proc. 4th Int. Conf. of Continuum Models of Discrete Systems, Stockholm, 311-327.

Ramsay, D. C., Colwell, J. B., Coffin, M. F., Davies, H. L., Hill, P. J., Pigram, C. J., and Stagg, H.M.J., 1986. New findings from the Kerguelen Plateau. Geology, 14:589-593.

Raymer, L. L., Hunt, E. R., and Gardner, J. S., 1980. An improved sonic transit time-to-porosity transform. Trans. SPWLA 21st Annu. Log. Symp., Paper P.

Rotstein, Y., Munschy, M., Schlich, R., and Hill, P. J., 1991. Structure and early history of the Labuan basin, Southern Indian Ocean. J. Geophys. Res., 96:3887-3904.

Rotstein, Y., Schaming, M., Schlich, R., and Colwell, J. B., 1990. Basin evolution in oceanic volcanic plateaus: seismic reflection evidence from the Kerguelen Plateau, South Indian Ocean. Mar. Pet. Geol., 7:1-12.

Rubey, W. W., and Hubbert, M. K., 1959. Role of fluid pressure in mechanics of overthrust faulting, Part 2. Geol. Soc. Am. Bull. 70:167-205.

Schaming, M., and Rotstein, Y., 1990. Basement reflectors in the Kerguelen Plateau, South Indian Ocean: indications for the structure and early history of the plateau. Geol. Soc. Am. Bull., 102:580-592.

Schlich, R., 1975. Structure et âge de l'océan Indien occidental. Mem. Hors-Ser. Soc. Geol. Fr., 6:1-103. 
Schlich, R., Coffin, M. F., Munschy, M., Stagg, H.M.J., Li, Z. G., and Revill, K., 1987. Bathymetric Chart of the Kerguelen Plateau. Jointly edited by Bureau of Mineral Resources, Geology and Geophysics, Canberra, Australia, Institut de Physique du Globe, Strasbourg, France, and Terres Australes et Antarctiques Françaises, Paris, France.

Schlich, R., Delteil, J., Moulin, J., Patriat, P., and Guillaume, R., 1971. Mise en évidence d'une sédimentation de marge continentale sur le plateau de Kerguelen-Heard. C.R. Acad. Sci., Ser. 2, 272:2060-2063.

Schlich, R., Munschy, M., Boulanger, D., Cantin, B., Coffin, M. F. Durand, J., Humler, E., Li, Z. G., Savary, J., Schaming, M., and Tissot, J. D., 1988. Résultats préliminaires de la campagne océanographique de sismique reflexion multitraces MD47 dans le domaine sud du plateau de Kerguelen. C.R. Acad. Sci., Ser. 2., 305:635-642.

Schlich, R., Wise, S. W., Jr., et al., 1989. Proc. ODP, Init. Repts., 120: College Station, TX (Ocean Drilling Program).

Schmoker, J. W., and Halley, R. B., 1982. Carbonate porosity versus depth: a predictable relation for south Florida. AAPG Bull., 66:2561-2570.

Sclater, J. G., and Christie, P.A.F., 1980. Continental stretching: an explanation of the post-mid-Cretaceous subsidence of the central North Sea basin. J. Geophys. Res., 85:3711-3739.
Sheriff, R. E., 1977. Limitation of resolution of seismic reflections and geologic detail derivable from them. In Payton, C. E. (Ed.), Seismic Stratigraphy: Application to Hydrocarbon Exploration. AAPG Mem., 26:3-14.

Tosaya, C., and Nur, A., 1982. Effect of diagenesis and clays on compressional velocities rocks. Geophys. Res. Lett., 9:5-8.

Wicquart, E., 1983. Modèle lithostratigraphique du plateau de Kerguelen-Heard, océan Indien [Thèse de troisième cycle]. Univ. Pierre et Marie Curie, Paris, France.

Wicquart, E., and Fröhlich, F., 1986. La sédimentation sur le plateau de Kerguelen-Heard: relations avec l'évolution de l'océan Indien au Cenozoique. Bull. Soc. Geol. Fr., 8:569-574.

Wyllie, M.R.J., Gardner, L. W., and Gregory, A. R., 1962. Studies of elastic wave attenuation in porous media. Geophysics, 27:569589.

Wyllie, M.R.J., Gregory, A. R., and Gardner, L. W., 1958. An experimental investigation of factors affecting elastic wave velocities in porous media. Geophysics, 23:459-493.

Date of initial receipt: 30 August 1990

Date of acceptance: 28 February 1991

Ms 120B-124 